\title{
Determinates of Personal Saving of Financial Institution Staff in Ethiopia: Case Study of Micro Finance Institutions (MFI) in Wolaita Sodo Town
}

\author{
Garedew Ganecho Gebremedihin \\ Department of Accounting and Finance, Wolaita Sodo University, Ethiopia
}

\begin{abstract}
Main objective of this research is to examine the determinants of personal saving of micro finance staff in Ethiopia, specifically in soddo town. it focused study the relationship between independent variable (personal saving) and dependent variables (behavioral characteristics of staff, financial literacy, continues increase inflation, government taxation, deposit interest rate, wealth). many finding confirms that saving habits in Ethiopia generally poor; to solve this problem descriptive research design and multiple linear regressions model was applied in this study and entire employees are taken from institution to gather research information. Primary data collected from 52 staff members, by using open and close ended questioner. The finding of the research shows that majority staff saving amount is between $1 \%$ up to $5 \%$, which is not adequate to cover future financial difficulties. From tasted dependent variables; behavioral characteristics of employees, financial literacy, deposit interest rate and wealth has positive significant relationship between the independent variable and inflation rate has negative significant relationship. Only government taxation has insignificant positive relationship with personal saving. Financial literacy and behavioral characteristics of employees are the major determinants of personal saving due to the strongest relationship with independent variable. To increase personal saving habit of staff; awareness as well as commitment for saving must be increased. Also micro finance institution should increase interest rate for deposit to motivate saving.
\end{abstract}

Keywords: Determinates, MFI, Personal saving

DOI: $10.7176 /$ RJFA/10-9-01

Publication date:May $31^{\text {st }} 2019$

\section{Introduction}

\subsection{Background of the study}

Personal savings on the part of consumers is an essential component in wealth accumulation and superiority both on micro- and macroeconomic growth, cited by (Robb, 2013) on (GAO 2001). Saving is vital tool for capital formation as well as has important contribution for economic growth, for a country that were able to accumulate high level of saving and thus high investments were seen to achieve rapid economic growths within the country (Todaro and Smith, 2012). Investment is important for sustainable economic growth which in turn is determined by the amount of domestic (national) saving of a country (Halefom, 2015). The simplest definition of "saving" that can be applied to all households is income minus consumption in a year (or other time period) (Browning \& Lusard, 1996).

"The poor households want to save, and do save...but it is not easy". Peoples need to save money in order to reduce their vulnerability to negative shocks, such as natural disasters, crop failures, job losses, illness or death in the family. With savings, in kind or in cash, a safety net is created. In a longer-term perspective, savings can contribute to increase the income base, for example by investing in the children's school education, for new sewing machine or to build accommodation. More stable people invest in land or other productive assets, (Rutherford, 2000).

Saving is the action of putting aside a part of current income, in order to invest or use it in future. The money saved will be deposited in bank, can be kept at home, or invested in different types of capital. Because many low-income households in developing countries have a small informal family business or a farm, they invest part of their savings in the production unit, in order to increase future income, (Isabel Dauner Gardiol, 2004). At macro level, saving in the form of capital creation is considered as essential weapon for economic growth as it increases capital stock thereby improving the ability of an economy to produce future economic advantage, (Donkor and Duah, 2013). Saving is strongly correlated with economic growth as suggested by neoclassical growth models, which stressed the importance of saving as an essential factor to economic growth of a country.

\subsection{Statement of the Problem}

Domestic savings in Africa are dominated by household savings that are not sufficiently canal into productive use (UNDP, 2007). Improving mobilization of saving could free up significant amounts of resources for investments that could promote economic growth. Understanding why and how households save, what 
determines their saving behavior particularly that of the poorer households can help identify appropriate policies that increase the amount of resources available for development. The purposes and meanings of saving, however, are different for each household, and are determined not only by income, but by the need to accumulate consumable goods (Wärneryd, 1989).

Saving money for a particular reason reflects specific personal values. Thus, the decision to save may not necessarily be related to a desire for financial safety or family prosperity (Canova, Rattazzi, \& Webley, 2005). To better understand the saving behavior of households, therefore, it is important to identify the attributes of each saving goal and the influence of human needs on the likelihood of saving. This will allow us to explore a model with greater applicability in empirical behavior to further study how to improve saving behavior. Focusing on psychological needs and the reasons for saving (beyond financial emergencies and retirement preparation) will expand the scope of saving behavior research by providing unique insights on the characteristics of household saving and the relative importance of certain saving goals. The projection of such psychological factors as needs and expectations into the need for saving distinguish this paper from classic saving behavior studies (Ewing \& Payne, 1998; Van Veldhoven \& Groenland, 1993; Wärneryd, 1989).

As per Tadele,(2015) finding in Ethiopia, saving mobilization and development of saving habits of a certain society will have an impact on capital accumulation and thus on economic growth of a country in general and on the financial security of the individuals in particular. Countries having higher level of saving rates have managed to reduce the burden of foreign debt and thus domestic investments will be financed by domestic saving. However many people are not interested for saving because of different reason as per (Tsega and Yemane, 2014) research done in Ethiopia, shows that lack of awareness and other socio saving culture are main factors that undermine saving behavior of people. As he concludes that saving culture of the society in general is poor in Ethiopia, even though the performance improvement of saving rate from 6 percent in 2006 to 9.5 percent in 2011 which is the poorest saving rate in the world and even in the Sub-Saharan countries the cause of which are many and diversified. Most paper conducted in Ethiopia shows us on the performance of saving in Ethiopia while overlook on factors that hinder saving performance. Then the researcher motivated to address this topic to understand on the role of certain factors for poor saving habits especially on microfinance employees who directly participated on saving mobilization activities.

1.3 Objective of the study and the research Questions :- General objective of this study is to analyze determinates of personal saving of financial institution staff in Ethiopia in case of Micro Finance Institutions (MFI) in Wolaita Sodo Town; Based on the above main objective, this study have the following specific objectives;

$\checkmark \quad$ To determine the extent of saving by Employees.

$\checkmark$ To examine determinants that affect the saving behavior of employees

\subsection{Research Hypothesis}

Ho: Behavioral Characteristics of Employees no significantly affects personal saving.

H1: Behavioral Characteristics of Employees significantly affect personal saving.

Ho: Financial Literacy is not significantly affects personal saving.

H1: Financial Literacy is one factor that significantly affects personal saving.

Ho: Continues increase Inflation rate is not significantly affects personal saving.

$\mathrm{H} 1$ : Continues increase inflation rate significantly affect personal saving.

Ho: Direct as well as indirect taxation not significantly affects personal saving.

H1: Direct as well as indirect taxation significantly affects personal saving.

Ho: The amount of deposit interest rate not significantly affects personal saving.

H1: The amount of deposit interest rate significantly affects personal saving.

Ho: Accumulate amount of resources (Wealth) of employees not significantly affects personal saving.

H1: Accumulate amount of resources (Wealth) of employees significantly affects personal saving.

\section{Literature reviews}

\subsection{Theoretical reviews}

As per Lunt and Livingstone economists and social scientists often consider saving to be what is left of disposable income after consumption is reduces by (Lunt \& Livingstone, 1991), but according to Katona (1975), thinking of the average person, saving refers to money put in bank accounts or other assets to protect one from future insecurities or to purchase goods and services (Katona, 1975; Lunt \& Livingstone, 1991). According to (Modigliani ,1970) assumption explains on a very simple version of the life-cycle model can predict that high growth causes high saving and he found empirical support for the theoretical prediction using cross-country data. More recently, Baumol, Blackman, and Wolfe (1991), Deaton and Paxson (1992), and Bosworth (1993) have also offers evidence that faster growth may raise saving. 


\subsubsection{How much should we save?}

The first question in our mined is how much should I save? The answer for this question is depending up on many condition, some conditions are controllable while other is beyond our capacity. According to (Pant, 2019), (Hill, 1928), (Weil, 2018) Argued that having financial success means being free to make choices based on your passions, and not out of economic necessity. To get financial freedom your monthly budget must be under. Most author advised that if you (we) spent 50\% Food, cloth and shelter, 30\% Education, life insurance and Recreation Finally $20 \%$ for Savings. This is called the 50/30/20 rule of thumb, and its popular quick-and-easy advice. As the result above explanation $20 \%$ of monthly income should be saved for future benefit.

\subsubsection{Determinants of saving}

As cited by (Nurul Wajh iAhmada, 2015), From an investment perspective, saving takes place when individual is able to spend less than income and set aside some amount of money every month. Yet, saving decision depends on many significant factors such as preferences of consumption, wealth, Goods and Services Tax and real interest rate. Inanition, the reasons for saving differ among income levels, with families at lower income levels saving for more immediate expenditures such as holiday gifts and rent, compared with the longer time frame of savings by higher income groups for future expenditures such as children's education and retirement (McKean et al., 2005). According (Wachtel, 1972), study focused on examining Personal taxes, the levels of and changes in the unemployment rate and inflations are variables that have impact on the saving rate. Demographic factor is more studied by other researcher, but lease studied determinates for saving are addressed by the researcher; those determinants are employees behavioral Characteristics, Financial Literacy, real interest rate, inflation, taxation; have been taken into account.

Behavioral Characteristics as determinant for saving: The Financial Capability Survey different from a number of other household surveys that collect Financial information in asking questions about behavioral characteristics, such as respondents' level of self control, time preference and whether or not they are well organized with their money. Time preference in financial decision-making is generally thought to capture an individual's choice of whether to spend their money now, or delay gratification for later, for example by saving; at the same time self-control is idea to be important influences on a person's financial decisions. Several studies have found that a preference for the future and self-control have a positive impact on saving, which is cited by (McCarthy, 2011) on (Walker, 1996), (Groenland and Nyhus, 1994; Lea et al., 1995).

Financial Literacy: Financial literacy can be defined as the ways how people manage:-their money in terms of insuring, investing, saving and budgeting (Mahdzan\&Tabiani, 2013). Financial literacy also defined as the ability to use knowledge and skills to manage financial resources effectively for a life time of financial wellbeing (Suwanaphan, 2013). Financial literacy is a skill that can help people to make financial decisions effectively. Therefore, individuals who are financially literate are expected to possess basic understanding of the financial concepts such as interest rate, inflation rate, compound interest, and risk (Sabri\&Juen, 2014).

Inflation: A major sources of uncertainty about consumer reactions concerns the way that price inflation, both expected and realized, influences consumer decisions about spending or saving. Which indicates consumers may be much more concerned that price inflation will erode their real income than pleased that rising nominal incomes will outweigh rising prices. If so, the appropriate reaction to inflationary expectations would be to curtail spending in an attempt to guard against declining real income, thus, as a consequence on raising the saving rate, (Wacht, 1972). Economists have usually taken the view that an expected rise in prices promotes an increase in expenditure: As result People will tend to substitute goods for money and thus to spend more and save less. As per (Richardson Kojo Edeme, 2015), research conclusion inflation and real interest to be negatively related with economic growth as well as saving capacity of people.

Taxation: Personal income taxes transfers' money from people to government, which the evidence suggests have a strong initial impact on observed saving behavior. It is fact that, Personal income taxes reduce disposable income relative to personal income (Wacht, 1972).

Real Interest rate: According to, Skinner (1998), Zeldes (1989), and Hansen and Sargent (2010), that cited on (Joshua Aizenman, 2017) states that the effect of the interest rate on saving is ambiguous. Where changing in the interest rate could have an income effect. That means when the interest rate are lower, expected level of saving is higher, because the lower rate of return from investment must be compensated by a higher saving rate. Hence, the predictive power of the interest rate and its sign depends on the relative magnitude of income and substitution effects. According to (Rekhi, -), the rate of interest is the reward for saving. Normally people save more when the rate of interest is high than when it is low. Thus people can be induced to save more by offering a high rate of interest. If the rate of interest raises people may voluntarily curtail their consumption to save more. Thus the rate of interest and consumption spending are inversely related.

Wealth: As per (Wikipedia, 2019), Concepts of wealth changed across time. Now a day wealth has been defined as accumulation of resources (net asset value), whether abundant or not. It is a collection of things limited in supply, transferable, and useful in satisfying human desires. In economics, wealth (in a commonly applied accounting sense, sometimes savings) is the net worth of a person, household, or nation - that is, the 
value of all assets owned net of all liabilities owed at a point in time. Adam Smith, described wealth as "the annual produce of the land and labor of the society". This "produce" is, at its simplest, that which satisfies human needs and wants of utility. In popular usage, wealth can be described as an abundance of items of economic value, or the state of controlling or possessing such items, usually in the form of money, real estate and personal property. Wealth can be categorized into three principal categories: personal property, including homes or automobiles; monetary savings, such as the accumulation of past income; and the capital wealth of income producing assets, including real estate, stocks, bonds, and businesses. All these delineations make wealth an especially important part of social stratification. Wealth provides a type of individual safety net of protection against an unforeseen decline in one's living standard.

\subsection{Empirical reviews}

Previously empirical studies, was focused on demographic that affect the amount of households deposit; According to (Huggett \& Ventura, 2000) study influencing factors for savings are different socio-demographic variables like age, ethnicity, presence of children, retirement status, human capital variables such as education and perceived health status, financial attitude variables, and economic variables, have all been linked to some aspects of saving decisions. Additional study conducted by (Niwanthika, 2016), on demographic factor for personal saving like; age, gender, marital status, consumption motives, education level, number of family members, religion, knowledge about savings, savings habits, risk tolerance, saving possibility, homeownership, household composition, self-employment, and unemployment have all been linked to some aspect of saving.

Other study emphasis on the relationship between savings motives and the values donated to or held in accounts as well as consumption patterns, predictive influence of saving motives on saving behavior and left over saving classifications. As per (Dynan, Skinner, \& Zeldes, 2004; Smith, 1999), (Canova, Rattazzi, \& Webley, 2005), (Central Bank Report, 2013), Finding saving motives is not necessarily mutually exclusive. For example, families may save for protective reasons but expect any unspent balances to be left as a bequest. People save for various reasons as old age, education, foreign travel, to buy goods, houses and lands, illness and hospitalization and to meet any unexpected expenses. As per above researcher, factors that have effects for saving are age, motives, savings habits, income uncertainty, income, wealth, risk tolerance, household composition, saving horizon, homeownership, health status, education, self-employment, and unemployment.

While other variables like, inflation, taxation, financial literacy, behavioral character, interest rates are studded but not in detail are emphasized in this paper.

\section{Research methodology}

3.1 Research Design: This study employed descriptive type of research design to show the opinion of the managers in Microfinance Institutions, to assess the factors that affect the performance of personal saving of Microfinance Institutions Employee. To do this, the researchers used both qualitative and quantitative approaches. Furthermore, in this study qualitative research approach is used to assess the opinion of the respondents towards the factors, their assumptions and the problems they faced. Quantitative approach was used to indicate the frequency and percentage of the responses.

3.2 Total population: In Wolaita Sodo town, there are three (Omo, Vision and Metemamen) Microfinance Institutions. From three micro finance institutions Metemamen is newly established; as result it excluded from this study. Totally 42 employees worked in omo Micro finance and vision fund also have 17 employees; then total target populations are 59 in both two institutions.

3.3 Sampling techniques: For the purpose of this study, the researchers used non probability sampling techniques. There are only 59 employees in two institutions, including the office head and workers. Because of small number, all of them are included in this study.

3.4 Methods of Data Collection instrument: To gather information from the respondents of the selected sample, the researchers developed a questionnaire which containing open and closed-ended questions. The questionnaires are distributed and filled with the support of selected enumerators. To check the clarity of the questionnaire before distribution the researcher test reliability and validity, as the result some modifications were made.

3.5 Model specification: - Multiple linear regression analysis was used, in order to achieve the second objective of the study i.e. to identify determinates variables that affect saving performance if MFI staff.

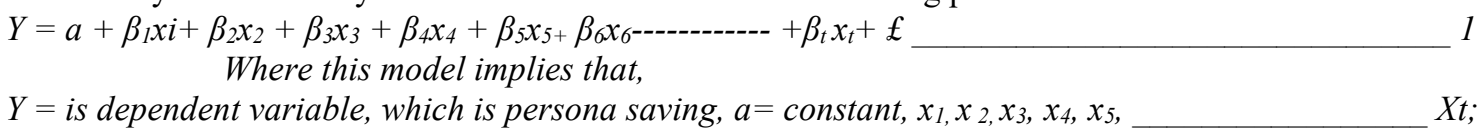


Are explanatory variables of the model and " $\epsilon$ " is unexplained part of the model. The unknown parameters are; $B 1, \beta 2, B_{3},----------\beta T$, are called the beta coefficients. The Model of this study has the following

$Y=\beta_{0}+\beta_{1} \chi 1+\beta_{2} \chi^{2}+\beta_{3} \chi^{3}+\beta_{4} \chi^{4}+\beta_{5} \chi^{5}+\beta_{6} \chi 6+£ i$, 2

Where: $\chi 1=$ Behavioral Characteristics, $\chi 2=$ Financial Literacy, $\chi^{3}=$ Inflation, $\chi^{4}=$ Taxation as a Factor, $\chi^{5}=$ Real Interest rate as a Factor: $\chi 6=$ wealth

3.6 Data analysis method: - In order to seek answers to research questions, both quantitative as well as qualitative types of data were used. The quantitative data was analyzed using SPSS software. Parametric test of data analysis such as Karl Pearson's product moment correlation and regression analysis were adopted with a value of 0.05 (level of significance) that corresponds to a $95 \%$ confidence level.

\section{Results and Discussion}

This Part of the paper explains the results of descriptive statistics and multiple liner regression results of the determinants of saving of MIF- staff. Questioner was distributed for 59 staffs but only 52 (88\%) questioner was returned back. The response was measured by using 5-point Likert scale.

\subsection{Reliability Statistics}

The research instrument was tested for reliability using the Cronbach's Alpha reported in below in table 4.1. The Cronbach's alpha for all dimensions are exceeding the minimum alpha value of 0.6 (Hair et al., 1998), thus the construct measures considered reliable and all items in the construct measures are retained.

\section{Table 4.1: Reliability Statistics}

\begin{tabular}{cc}
\hline Cronbach's Alpha & N of Items \\
.939 & 7 \\
\hline
\end{tabular}

Table 4.1, Result shows that the alpha value (.939) of all variable is above 0.6 , the study instruments yielded fairly reliable data for this research, thus measuring the relationship between independent and dependent variables was reliable and valid

Table 4.2:- Personal information

\begin{tabular}{|c|c|c|c|c|c|c|c|c|c|c|c|}
\hline \multicolumn{4}{|c|}{ Sex } & \multicolumn{4}{|c|}{ Age } & \multicolumn{4}{|c|}{ Education } \\
\hline & & Frequency & $\%$ & Val & & Frequency & $\%$ & & & Frequency & $\%$ \\
\hline \multirow{3}{*}{$\frac{\pi}{\pi}$} & Male & 29 & 55.8 & \multirow{3}{*}{$\frac{\bar{\pi}}{\bar{\pi}}$} & $<25$ Year & 15 & 28.8 & \multirow{3}{*}{ : } & Certificate & 1 & 1.9 \\
\hline & Female & 23 & 44.2 & & 25-40 Year & 35 & 67.3 & & Diploma & 11 & 21.2 \\
\hline & Total & 52 & 100 & & > 40 Year & 2 & 3.8 & & Degree & 40 & 76.9 \\
\hline & \multicolumn{2}{|c|}{ Survey 2019} & & \multicolumn{2}{|c|}{ Total } & 52 & 100 & & Total & Total & 100 \\
\hline
\end{tabular}

The result of study presented on table 4.2 indicates that 29(55.8\%) of employees are male and 23(44.2\%) of staff are female who participated in this study. Majority respondent $35(67.3 \%)$ have an age between 25 up to 40 year old. Educational background of respondent implies that $1.9 \%$ have certificate, $21 \%$ have diploma and majority of them $40 \%$ are degree holders. Then the researcher concluded that MFI- has young end educated staffs from both sex.

Table 4.3:-Amount of monthly income and the extent of saving

\begin{tabular}{|c|c|c|c|c|c|c|c|}
\hline \multicolumn{4}{|c|}{ Monthly income (in Birr)? } & \multicolumn{4}{|c|}{ Monthly saving amount (in percent)? } \\
\hline & & Frequency & $\%$ & & & Frequency & $\%$ \\
\hline \multirow{5}{*}{$\begin{array}{l}\frac{\pi}{\pi} \\
>\end{array}$} & $1001-3000$ & 5 & 9.6 & \multirow{5}{*}{$\begin{array}{l}\text { 믐 } \\
\stackrel{\pi}{>}\end{array}$} & $1 \%-5 \%$ & 29 & 55.8 \\
\hline & $3001-5000$ & 5 & 9.6 & & $5 \%-10 \%$ & 13 & 25.0 \\
\hline & $5001-10,000$ & 42 & 80.8 & & $10-15 \%$ & 9 & 17.3 \\
\hline & \multirow[t]{2}{*}{ Total } & \multirow[t]{2}{*}{52} & \multirow[t]{2}{*}{100} & & $15-20 \%$ & 1 & 1.9 \\
\hline & & & & & Total & 52 & 100 \\
\hline
\end{tabular}

Survey 2019

Table 4.3 Indicates that majority employees get more than five thousand birr and less than ten thousand Ethiopian Birr, from monthly income more than half $55.8 \%$ of staff saved less than $5 \%$, which is extremely less than from expected amount of saving.

Table 4.4:- Model summary

\begin{tabular}{|c|c|c|c|c|c|}
\hline \multirow{3}{*}{ 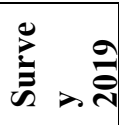 } & \multicolumn{5}{|c|}{ Model Summary } \\
\hline & Model & $\mathrm{R}$ & R_Square & Adjusted R Square & Std. Error of the Estimate \\
\hline & & $.974^{\mathrm{a}}$ & .950 & .943 & $\begin{array}{r}202 \\
\end{array}$ \\
\hline \multicolumn{6}{|c|}{$\begin{array}{l}\text { a. Predictors: (Constant), Wealth, Behavioral Characteristics, Inflation rate, Financial Literacy, Deposit } \\
\text { Interest Rate, Taxation } \\
\text { b. Dependent Variable: Personal saving }\end{array}$} \\
\hline
\end{tabular}


Table 4.4, shows the result from the analysis that relationship exists between the independent variables and dependent variable. The model was significant by establishing a relationship between dependent variable and independent variables. The coefficient of determination (R2) is 0.95 , which indicate that 95 percent of the variations in dependent variable and independent variables which means the personal saving can also be influenced by about 5 percent of variables which are not in the model. Therefore, the researcher concluded that, there is significant relationship between dependent variable and independent variables.

Table 4.5 Coefficients ${ }^{\text {a }}$

\begin{tabular}{|c|c|c|c|c|c|c|}
\hline \multirow{2}{*}{\multicolumn{2}{|c|}{ Model }} & \multicolumn{2}{|c|}{$\begin{array}{l}\text { Un standardized } \\
\text { Coefficients }\end{array}$} & \multirow{2}{*}{$\begin{array}{r}\begin{array}{l}\text { Standardized } \\
\text { Coefficients }\end{array} \\
\text { Beta }\end{array}$} & \multirow[t]{2}{*}{$\mathrm{t}$} & \multirow[t]{2}{*}{ Sig. } \\
\hline & & B & Std. Error & & & \\
\hline \multirow{7}{*}{ 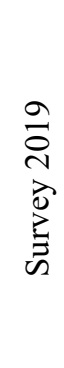 } & (Constant) & -.069 & .159 & & -.430 & 670 \\
\hline & $\begin{array}{l}\text { Behavioral } \\
\text { Characteristics }\end{array}$ & .317 & .094 & .317 & 3.370 & .002 \\
\hline & Financial Literacy & .369 & .078 & .370 & 4.749 & .000 \\
\hline & Inflation rate & -.147 & .058 & -.132 & 2.541 & .015 \\
\hline & Taxation & .053 & .054 & .056 & 0.975 & .335 \\
\hline & Deposit Interest Rate & .304 & .070 & .304 & 4.331 & .000 \\
\hline & Wealth & .131 & .048 & .123 & 2.719 & .009 \\
\hline
\end{tabular}

From the table 4.5 above, the constant gave a value of -.069 which is the intercept, hence establishing a negative relationship because of the negative value while the row contains the name of the Independent Variable (Personal saving ) which refers to the slope. The table also shows the t statistics which helped to determine the relative importance of each variable in the model and this is known by the independent variable whose values are well below -2 and above +2 . Any value below -2 and above +2 will be accounted for as less improvement in the procedure and techniques. The value for the independent variables (Except taxation) are statistically significant, this also explain the establishment of a relationship between the independent variables and the dependent variabls. According to (Malhotra, 2010) the researcher will accept research hypotheses of the study, when pvalues are less than 0.05 . As the result; from this study the researcher concluded that government taxation has insignificantly effect on personal saving while all other independent variables significantly predicted Personal saving. As the p-value is less than .05 , we reject the null hypothesis and accept the alternative hypothesis that, there is significant positive relationship between the dependent variable (personal saving) and independent variables (employees' behavioral characteristics, financial literacy, deposit interest rate, finally previously accumulated resource of employees) and significant negative relationship between the personal saving and Inflation rates. Whereas the p-value of government taxation is greater than .05 ; then we accept the null hypothesis and reject the alternative hypothesis that, there is insignificant positive relationship between the personal saving and government taxation.

Table 4.6: Summary of Pearson Correlation Analysis

\begin{tabular}{|c|c|c|c|}
\hline \multirow{8}{*}{ 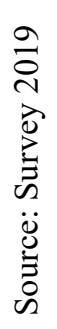 } & & Pearson Correlation & Sig. (2-tailed) \\
\hline & Personal saving & 1 & \\
\hline & Behavioral Characteristics & .932 & .000 \\
\hline & Financial Literacy & .932 & .000 \\
\hline & Inflation rate & .580 & .000 \\
\hline & Taxation & .736 & .000 \\
\hline & Deposit Interest Rate & .862 & .000 \\
\hline & Wealth & .665 & .000 \\
\hline
\end{tabular}

Correlation is significant at the 0.05 level (2-tailed).

According to above table 4.6, all the independent variables have positive association with the dependent variables. Behavioral Characteristics and Financial Literacy has the strongest relationship with personal saving ( $\mathrm{r}$ $=0.932)$, Deposit Interest Rate $(\mathrm{r}=0.862)$, Taxation $(\mathrm{r}=0.736)$, wealth $(\mathrm{r}=0.665)$ and Inflation $(\mathrm{r}=0.580)$. Behavioral Characteristics and Financial Literacy is the major determinants of Personal saving due to the strongest relationship with Personal saving.

\section{Conclusion and recommendation}

Two specific objectives was tasted; that is (I) Determine the extent of saving and (II) Examine the major determinants that affect the personal saving of financial institution. The Researcher Hypothesis that Behavioral Characteristics, Financial Literacy, Continues increase Inflation, Direct as well as indirect taxation, the amount of deposit interest rate, Accumulate amount of resources (Wealth) affects personal saving of Microfinance 
Institutions Staff. Micro finance staff have responsibility to mobilize the required amount saving form public as whole but the findings of the research shows that majority staff saving amount is between $1 \%-5 \%$, which is not adequate to cover future financial difficulties. For this less amount of saving different variables has its own effect. Form the researche haypothis Except government taxation all other independent variables (Behavioral characteristics of employees, financial literacy, deposit interest rate, wealth) has positive significant relationship between the personal saving and Inflation rate has negative significant relationship. Null hypothesis was rejected and accepted the alternative hypothesis for significant relationship between the personal saving and (Employees' behavioral characteristics, financial literacy, inflation rate, deposit interest rate and wealth), for significant negative relationship between the personal saving and finally accepted the null hypothesis and reject the alternative hypothesis that, for insignificant positive relationship between the personal saving and government taxation. Both Financial Literacy and Behavioral Characteristics of employees are the major determinants of Personal saving due to the strongest relationship with Personal saving. To increase personal saving tendency of staff; staff awareness as well as commitment for saving must increase. To make MFI should consistently educate staff about the importance of improving saving behavior also they should introduce workplace-based financial education programs. According to Shepellfgi Research Group (2009), these programs have proven to be quite effective in helping employees make better financial decisions and reduce their financial related stress. Institution should improve individuals' organizational skills and devices to, as much as is possible, minimizes the impact of behavioral and psychological personality financial outcomes. Micro finance institution should increase interest rate for deposit which was paid for saving by considering interest rate collected form borrower, big gap between paid and collected interest rate decrease the motive of people to save in MFI; especially staffs that have detail knowledge are more dispirited with this issue.

\section{Reference}

1. Barry bosworth, g. B. (1991). The Decline in Saving: Evidence from Household Surveys . 12-13.

2. Baumol, W.J., Blackman, S.A.B., and Wolfe, E.N., (1991). Productivity and American Leadership: The Long View. Cambridge: MIT Press.

3. Birkeland, F. B. (2013). The saving motives of Dutch households And the effect of individual characteristics on the importance of saving motives. Kristiansan , 16-19.

4. Browning, M., \& Lusardi, A. (1996). Household saving: Micro theories and micro facts. Journal of Economic Literature, 34(4), 1797-1855.

5. Canova, L., Rattazzi, A. M., \& Webley, P. (2005). The hierarchical structure of saving motives. Journal of Economic Psychology, 26(1), 21-34.

6. Chang, Y. R. (1994). Saving behavior of U.S. households in the 1980s: Results from the 1983 and 1986 Survey of Consumer Finances. Financial Counseling and Planning, 5, 1-21.

7. Conde Bonfil C. (2001), Depósitos o puerquitos? Las decisions de ahorro en México. El Colegio Mexiquense, Unión de Esfuerzos para-el Campo - La Colmena Milenaria, México.

8. Dauner Isabel (1998), Demanda de services de ahorro en laszonas de incidencia Del Fondo de Desarrollo Local. Nitlapán-UCA, Nicaragua. Mimeo.

9. Deci, E., \& Ryan, R. (2000). What and why of goal pursuits: Human needs and the self- determination of behavior. Psychological Inquiry, 11(4), 227-268.

10. Donkor, J. and Duah, F.(2013). "Relationship between Savings and Credit in Rural Banks with Specific Reference to Ghana", International Journal of Business and Social Science, 4(8). Egwu

11. Dynan, K. E., Skinner, J., \& Zeldes, S. P. (2004). Do the rich save more? Journal of Political Economy, 112, 397-444.

12. Ewing, B. T., \& Payne, J. E. (1998). The long-run relation between the personal savings rate and consumer sentiment. Journal of Financial Counseling and Planning, 9(1), 89-96.

13. Friedman, M. 1957. The Permanent Income Hypothesis: A Theory of the Consumption Function. Princeton, NJ: Princeton University Press. ISBN 0-691-04182-2.

14. Fisher, P. J. (2010). Gender differences in personal saving behaviors. Journal of Financial Counseling and Planning, 21, 14-24.

15. Foster, J. F. (1981). The reality of the present and the challenge of the future. Journal of Economic Issues, $15,963-968$

16. Ford, M. E. (1992). Human motivation: Goals, emotions, and personal agency belief. Newbury Park, CA: Sage

17. Furnham, A. (1985). Why Do People Save? Attitudes to, and Habits of, Saving Money in Britain. Journal of Applied Social Psychology, 15(4), 354-373.

18. Goldstein G., Barro I. (1999), Etude sur le rôle et limpact des services et produits d'épargne du secteur informel et des institutions de microfinance en Afrique de l'Ouest. PNUD-FENU, Special Unit for Microfinance (SUM), Micro Save-Africa. Mimeo. 
19. Halefom. Y. (2015). "Determinants of household saving in Gedeo zone, Southern Ethiopia”. Journal of Economics and Sustainable Development, 6 (7). Hussein,

20. Hair, J. F., Anderson, R. E., Tatham, R. L., \& Blank, W. C. (1998). Multivariate data analysis, 5th Ed., Prentice-Hall, Englewood Cliffs, NJ

21. Huggett, M., \& Ventura, G. (2000). Understanding why high income households save more than low income households. Journal of Monetary Economics, 45(2), 361397.

22. Hefferan, C. (1982). Determinants and patterns of family saving. Home Economics Research Journal, 11, 47-55

23. Isabel Dauner Gardiol, I. B. (2004). Mobilizing savings, key issues and good practices in savings promotion. Swiss Agency for Development and Cooperation, $S D, 3$.

24. Joshua Aizenman, Y.-W. C. (April 2017). The interest rate effect on private saving: alternative perspectives . ADB Institute, 9-10.

25. Keynes, J. M. (1936). The general theory of employment, interest and money. London: Macmillan.

26. Levine, R. and Renelt, D., (1992). A Sensitivity Analysis of Cross-Country Growth Regressions. American Economic Review, 82: 942-963.

27. Lindqvist, A. (1981). Hushållens sparande. Beteendevetenskapliga måtninger av hushållens sparbeteende [The Saving Behaviour of Households. Subjective measures of households' saving behavior]. Stockholm, Sweden: Unpublished doctoral dissertation, The Stockholm School of Economics.

28. Lunt, P., \& Livingstone, S. (1991). Psychological, social and economic determinants of saving: Comparing recurrent and total savings. Journal of Economic Psychology, 12, 621-641.

29. McCarthy, Y. (2011). Behavioural characteristics and financial distress . European Central Bank, 9-12.

30. McKean, L., Lessem, S., Bax, E. \& Hernandez, N. (2005). Money management by low-income households: earning, spending, saving, and accessing financial services. Center for Impact Research.

31. Modigliani, F., (1970). The Life Cycle Hypothesis of saving and Intercoun- try Differences in the Saving Ratio. Induction, Growth, and Trade, (eds.) W.A. Eltis, M.F.G. Scott, and J.N. Wolfe. Oxford: Clarendon Press

32. Niwanthika, T. T. (2016). Determinants of Personal Savings: A Review of Literature . 1.

33. Nurul Wajh iAhmada, M. r. (2015). Determinants of Saving Behavior among Staff in International Islamic University College Selango. Atlantis Press, 1.

34. Pant, P. (2019). Google. Retrieved 3 20, 2019, from https: //www. Google .com/ search? client = firefox-b$\mathrm{d} \& \mathrm{q}=$ how + much + money+should+be+saved\%3f: https: //www.tiaa. org

35. Rekhi, S. (-). Google. Retrieved 04 02, 2019, from http://www.economics discussion.net/ consumptionfunction/top- 9-factors-affecting- household-consumption-and- saving/20683

36. Richardson Kojo Edeme, I. I. (2015). Savings, Inflation and Economic Growth Linkages: A ReExamination with Nigeria Data . www.sciencepublishinggroup.com/j/jim), 2 .

37. Romer, P.M., (1987). Crazy Explanations for the Productivity Slowdown. NBER Macroeconomics Annual.

38. Robb, P. B. (2013). Financial Literacy and Emergency Saving. Springer Science+Business Media New York, 1.

39. Rutherford S. (2000), the Poor and Their Money. Oxford University Press, New Delhi, India. Mutesasira L. (1999), Savings and Needs: An Infinite Variety. Micro Save-Africa, Kampala, Uganda.

40. Ruthven O. (2001), "Money Mosaics: Financial Choice and Strategy in a West Delhi Squatter Settlement". Working Papers Series no. 32, Nov. 2001. Finance and Development Research Programme, University of Manchester.

41. Tadele, M. (2015). “Household saving behavior in Jimma zone of Oromia Region, Ethiopia”, International Journal of Research in Commerce, It and Management, 5(3).

42. Todaro, M. And Smith, P. (2012). "Economic development", 11 th Eds.Addison-Wesley, Boston.

43. Tolosa Negesse (2011) The role of microfinance institutions on poverty reduction and improving living standards, M.sc thesis ,Addis Ababa University, Addis Ababa

44. Tsega, H. and Yemane, M. (2014). "Determinants of household saving in Ethiopia: A case of north Gondar zone, Amhara regional state". International Journal of Development and Economic Sustainability, 2(4), $37-$ 49

45. United Nations Development Program (UNDP).(2007). "Economic development in Africa: Reclaiming policy space", Conference on trade and development of domestic resource mobilization and developmental states, New York.

46. Van Veldhoven, G. M., \& Groenland, E. A. (1993). Exploring saving behavior: A framework and a research agenda. Journal of Economic Psychology, 14(3), 507-522.

47. Xiao, J. J., \& Noring, F. E. (1994). Perceived saving motives and hierarchical financial needs. Journal of Financial Counseling and Planning, 5, 25-44.

48. Wärneryd, K. (1989). On the psychology of saving: An essay on economic behavior. Journal of Economic 
Psychology, 10(4), 515-541.

49. Weil,L.(2018,March2).Google.Retrieved3,/20,2019,fromhttps://thecreativeindependent.com/guid

es/anartists-guide-to-financial-planning/:https:// thecre ativein dependent.com.

50. Wikipedia. (2019, March 30). Wikipedia, the free encyclopedia. Retrieved 4 5, 2019, from Google: https://en.wikipedia.org/wiki/Wealth

51. Zeldes, S. P. (1989). Consumption and liquidity constraints: An empirical investigation. Journal of Political Economy, 97, 305-346 